\title{
Legal and economic arguments for the protection of advertising value through trade mark law
}

\author{
Apostolos Chronopoulos \\ Research and Teaching Assistant, Centre for Commercial Law Studies, Queen Mary University of London
}

Traditionally, trade mark theory has been reluctant to protect advertising value from appropriation by third parties. Various justifications for this proposition have been put forward, most notably the free-riding theory associated with overbroad trade mark monopolies, the ethical condemnation of the 'branding personality', and the waste of economic resources spent on persuasive advertising. As a result, the system of protection established by the Trade Marks Directive has relied predominantly on theories of liability that require some kind of consumer confusion or dilutive harm. Thus, protection against the appropriation of advertising value has been confined to marks with a reputation. However, both marketing and economics literature suggest that there are sufficient grounds militating in favour of a general protection against the commercial appropriation of advertising value and that, rather than constituting an insurmountable persuasive force, the brand image simply constitutes a good that is demanded by consumers as a complement to some basic product. This article argues that far from being bound by the notion of parasitic competition, the free-riding theory finds its actual justification in the promotion of a dynamic competition with differentiated products. In addition, it is the best analytical instrument we have at the moment for the legal evaluation of the complex phenomenon of brands and the balance of the various interests involved in the respective disputes.

Keywords: advertising function, dilution, free-riding, goodwill, misappropriation, product differentiation, trade marks, competition, market power, unfair advantage, L'Oréal, Specsavers, Sabel

\section{INTRODUCTION}

Traditionally, trade marks have been analysed with reference to their functions in the marketplace. ${ }^{1}$ Numerous functions have been described for the purpose of defining the scope of trade mark rights. Above all, trade marks are communicative instruments conveying various types of information codified in symbolic form. ${ }^{2}$ Their communicative uses include, designating the commercial source of products and services, transmitting signals of quality to consumers, providing consumers with information about the trade

1. On the modern approach to the 'functional analysis' of trade mark law see generally, J Mellor, D Llewelyn, T Moody-Stuart, D Keeling and I Berkeley, Kerly's Law of Trade Marks and Trade Names (15th edn, Sweet \& Maxwell, London 2011) at [2-010]-[2-020].

2. $\quad$ R Schreiner, Die Dienstleistungsmarke, Typus, Rechtsschutz und Funktion (Munich: Heymanns, 1983) 448 et seq.; M Strasser, 'Rational Basis of Trademark Protection Revisited: Putting the Dilution Doctrine into Context' (1999-2000) 10 Fordham Intell. Prop. Media \& Ent. L.J. 375, 382. 
marked goods and carrying along with them some marketing message. ${ }^{3}$ Trade marks encapsulate the attractiveness of a brand image generated by the advertising strategies of their proprietor. ${ }^{4}$ The so-called advertising function of trade marks describes their capacity to trigger sales and retain custom. ${ }^{5}$ Exclusive rights in trade marks are meant to protect the intangible value of goodwill, which could be broadly defined as comprising all factors that contribute to consumer patronage. ${ }^{6}$ Throughout the years, court opinions and legal scholars have expressed scepticism over the advertising function. ${ }^{7}$ Objections refer to the monopolistic elements inherent in branding activity, which allow the right holder to charge supra-competitive prices. Furthermore, goodwill exercises a persuasive influence on consumers' buying decisions. Instead of concentrating skill and effort on improving product quality, sellers supposedly waste resources through advertising expenditures that do not serve informative purposes but are directed at creating a brand image. Brand loyalty has also been considered as a sign of the 'ethical decadence' of modern society. Therefore, the protection of the advertising function constitutes, according to this view, either an exceptional theory of infringement reserved for well-known marks or a necessary evil that comes along with the implementation of the origin function. On top of everything, the protection of advertising value would give rise to trade mark rights in gross without any redeeming benefit to the public interest against consumer confusion. Trade mark propertization would enhance the exclusionary effect of trade marks on competition without any increase in consumer welfare.

This paper suggests that there are enough legal and economic arguments that militate in favour of the exactly opposite view. Part 2 deals with the nature of the proprietary interests of the trade mark holder as exclusive authorities, which have to be reconciled with the public interest. Due to their origins in passing-off, trade mark rights have found their legitimacy in the public policy against consumer confusion. With the exception of well-known marks, exclusive rights in trade marks have been difficult to justify beyond these boundaries. A more nuanced approach is proposed that considers trade marks as part of the broader set of norms regulating the effectiveness of competition. Accordingly, it might well be that some expansions of trade-mark scope would increase consumer welfare in respects other than the promotion of market transparency. Part 3 brings forward the argument that the protection of the advertising function would stimulate dynamic competition with differentiated products. The

3. K-H Fezer, Markenrecht (4th edn, Beck, Munich 2009), Einl. D.

4. Opinion of Advocate-General Ruiz-Jarabo Colomer, Arsenal Football Club Plc v Reed, Case C-206/01, [2003] R.P.C. 9 at [46]-[47]: 'It seems to me to be simplistic reductionism to limit the function of the trade mark to an indication of trade origin. The Commission, moreover, took the same view in its oral submissions to the Court. Experience teaches that, in most cases, the user is unaware of who produces the goods he consumes. The trade mark acquires a life of its own, making a statement, as I have suggested, about quality, reputation and even, in certain cases, a way of seeing life. ... When I regard the current functioning of the market and the behaviour of the average consumer, I see no reason whatever not to protect those other functions of the trade mark and to safeguard only the function of indicating the trade origin of the goods and services'.

5. R Callmann and L Altman, Unfair Competition, Trademarks and Monopolies (4th edn, Thomson/West, Eagan, MN 2004) § 17.04; M Strasser, 'Rational Basis of Trademark Protection Revisited', supra (n 2) at 386-90.

6. ES Rogers, Goodwill, Trade-Marks and Unfair Trading (Shaw, Chicago 1914) 13; R Callmann and L Altman, Unfair Competition, Trademarks and Monopolies, supra (n 5) § 1.11. 7. See for example the critical analysis of G Ghidini, Innovation, Competition and Consumer Welfare in Intellectual Property Law (Edward Elgar, Cheltenham 2010), 188-91. 
protection of the advertising function would enhance consumer welfare by increasing product variety in the relevant market and intensifying competition on better matching consumer preference for differentiated goods. Free-riding upon the goodwill attached to a senior trade mark amounts to a misappropriation because it undermines consumer welfare. Hence, the paper constructs a system of trade mark protection based on economic models of monopolistic competition. Proprietary interests in trade marks for the purpose of effectuating brand extensions may also be justified by the welfare effects resulting from umbrella marketing, which reduces the seller's moral hazard. In addition, the paper addresses the concerns over the negative implications of persuasive advertising and resolves some misunderstandings in regard to the exclusionary effect of trade marks. Part 4 highlights the limitations applicable to the protection of the advertising function. Part 5 revisits some important cases of the CJEU related to the protection of advertising value.

\section{TRADE MARKS: JUSTIFICATIONS BASED ON PROPERTY AND PASSING-OFF}

\subsection{The passing-off origins: still haunting trade mark law?}

Two modes of thought have always been competing for shaping the modern law of trade marks: ${ }^{8}$ the tort law principles on passing-off and the award of property rights. Without doubt, passing-off principles promulgated the legal protection of trade marks as communicative instruments that signify commercial origin. ${ }^{9}$ Courts used those days to hold that the junior use of a trade mark was an act of fraud against both the public and the senior user. ${ }^{10}$ By making misrepresentations as to the source of their products,

8. Cf. the distinction between the deception- and the property-based approach to trade marks as drawn by Advocate General Niilo Jääskinen in Interflora Inc, Interflora British Unit v Marks \& Spencer Plc, Flowers Direct Online Ltd, Case C-323/09, [2012] E.T.M.R. 1 at [50]: 'Trade mark dilution relates to the idea that the proper purpose of trade mark law should be to protect the efforts and investments made by the trade mark proprietor and the independent value (good will) of the trade mark. This "property-based" approach to trade marks differs from the "deceptionbased" idea that trade mark law primarily protects the origin function with a view to preventing consumers and other end users from erring as to the commercial origin of goods and services. The property-based approach also protects the communication, advertising and investment functions of trade marks with a view of creating a brand with a positive image and independent economic value (brand equity or good will)'.

9. L Bently, 'From Communication to Thing: Historical Aspects of the Conceptualization of Trademarks as Property', in GB Dinwoodie and MD Janis (eds), Trademark Law and Theory: A Handbook of Contemporary Research (Edward Elgar, Cheltenham 2008) 8-12; W Derenberg, Trade-Mark Protection and Unfair Trading (Bender, Albany, NY 1936) 42-7; C RamirezMontes, 'A Re-Examination of the Original Foundations of Anglo American Trademark Law' (2010) 14(1) Marq. Intell. Prop. L. Rev. 91, 100-9; FI Schechter, The Historical Foundations of the Law Relating to Trademarks (Columbia University Press, New York 1925) 141-5.

10. Perry v Truefitt [1842] 49 E.R. 749, 752 (Lord Langdale): 'I think that the principle on which both the Courts of law and of Equity proceed, in granting relief and protection in cases of this sort, is very well understood. A man is not to sell his own goods under the pretence that they are the goods of another man; he cannot be permitted to practise such a deception, nor to use the means which contribute to that end. He cannot therefore be allowed to use names, marks, letters, or other indicia, by which he may induce purchasers to believe, that the goods which he is selling are the manufacture of another person. I own it does not seem to me that 
the junior users were able to induce deceived consumers into a transaction and thereby divert trade from competitors, all in a fraudulent manner. ${ }^{11}$ Notably, the interest positions of the senior trade mark user and the consuming public did coincide under the passingoff cause of action. After all these years, it seems that there is a prevailing consensus among commentators that trade mark law should not sensationally go beyond the contours set out by passing-off. Expansions of trade mark scope would in the meantime only take place if they could simultaneously vindicate the consumer's interest in avoiding some sort of confusion. Eventually, right holders were authorized to enjoin third parties from using their trade marks in ways which led consumers to believe that the senior and the junior user share some commercial, economical or other organizational affiliation. Reverse confusion fits within the passing-off framework as well. When the junior user creates the impression in the public that the goods of another are his own, consumers are misled and the senior user is likely to sustain loss. Initial interest confusion is a more controversial theory of infringement. Consumer confusion about the commercial source of products or services is only temporary, but the junior user profits from the association made to the senior mark in that he has managed to attract the attention of the public to his own trade. Indeed, the doctrine of initial interest confusion constitutes a significant departure from the philosophy of traditional passing-off principles. ${ }^{12}$

Many prominent commentators have expressed their concerns about the foreclosure effect of overbroad trade mark rights and plead for confining the trade mark holder to the authority of excluding only those junior uses that cause confusion as to source. ${ }^{13}$ Most recently, Lemley and McKenna have proposed that trade mark claims should only be given effect by the courts when there is indeed confusion as to the source of goods or when consumers are likely to believe that the right holder guarantees the quality of the products marketed by the defendant under an identical or similar mark. ${ }^{14}$ For other types of confusion to be actionable, the plaintiff must show, just like in false advertising claims, that the confusion dispelled by the junior use is likely to exercise decisive influence on the buying decisions of the consumer. ${ }^{15} \mathrm{~A}$ good example is the so-called merchandising right. Confusion as to sponsorship or affiliation should not be actionable unless it is likely to induce consumers into buying the product bearing the senior mark as an embellishment. The imposition of a materiality requirement is meant to restrict the exclusionary effect of trade marks to the authority of prohibiting those junior uses that cause confusion, which is likely to adversely affect the market mechanism by distorting consumers' decisions to purchase. In short, Lemley

a man can acquire a property merely in a name or mark; but whether he has or not a property in the name or the mark, I have no doubt that another person has not a right to use that name or mark for the purposes of deception, and in order to attract to himself that course of trade, or that custom, which, without that improper act, would have flowed to the person who first used, or was alone in the habit of using the particular name or mark' (summarizing an established legal practice and denying to follow the property rationale as set out in Millington v Fox).

11. Lever v Goodwin [1887] Ch.D., 4 RPC 492, 498.

12. For a critical view on the doctrine of initial interest confusion see JE Rothman, 'Initial Interest Confusion: Standing at the Crossroads of Trademark Law' (2005) 27(1) Cardozo L. Rev. 105. See, however, the recent case of Och-Ziff. v Och Capital [2011] F.S.R. 11.

13. GB Dinwoodie, 'The Rational Limits of Trademark Law', in H Hansen (ed.), US Intellectual Property Law and Policy (Edward Elgar, Cheltenham 2006) 59; MA Lemley, 'The Modern Lanham Act and the Death of Common Sense' (1999) 108 Yale L.J. 1687; GS Lunney, Jr, 'Trademark Monopolies' (1999) 48 Emory L.J. 367.

14. MA Lemley and MP McKenna, 'Irrelevant Confusion' (2010) 62 Stan. L. Rev. 413, 446-50.

15. Ibid. 
and McKenna support the introduction of a 'trade mark injury' requirement drawing a parallel to the requirement of 'antitrust injury'. ${ }^{16}$ From a doctrinal point of view, their model is a very elaborate attempt to anchor trade mark law to its traditional moorings in the law of passing-off. ${ }^{17}$

\subsection{Trader interests in perspective: trade marks as property rights}

At some point in the course of legal development, the legal concept of property was introduced into the law of trade marks as a method of protection that was distinct from tort law principles. Interrupting the established legal treatment of trade marks as instruments of fraud in the context of passing-off, an English Chancery Court recognized in the great case of Millington $v$ Fox that the plaintiff has a property interest in the mark he had adopted and used first. ${ }^{18}$ Above all, the property rationale contributed to the legal development of trade mark law in that it emphasized that traders have a legitimate interest in the exclusive use of a source identifier. ${ }^{19}$ Otherwise, communication to the consumers would not be efficient, meaning that the senior trade mark user would not be able to create and exploit goodwill. This interest is independent from findings of confusion as to source. Art 5(1)(a) TMD is a manifestation of the notion that there exist proprietary interests of the right holder, which should be vindicated even though the junior use of the trade mark does not cause consumer confusion. The prohibition against identical uses serves as a kind of dilution protection below the threshold of reputation. In order to eventually operate as a source designator in the marketplace, a trade mark should remain unique at least within the narrow segment of products in connection with which it is actually being used. In addition, banning identical uses is a means to combat product piracy.

The property rationale shifted the focus of the analysis to the interest position of the right holder. Hence, the dilution theory was incepted for the purpose of securing the effectiveness of those trade marks that concentrated considerable selling power. ${ }^{20}$ Trade mark rights may allow the right holder to enjoin non-competing uses of his trade mark so as to protect his future business interests in expanding his trade to other, even distant, markets. ${ }^{21}$ The authority to prohibit the junior use of a trade mark in unrelated goods aims at protecting the goodwill of the right holder from possible damage that would accrue if the junior user marketed low quality goods under the same mark. ${ }^{22}$ Even if there was no seller moral hazard on the behalf of the junior user, the authority to enjoin non-competing uses could be justified with the argument that the trade mark holder should have the right to define the content of the goodwill

16. MA Lemley and MP McKenna, 'Owning Mark(et)s' (2010) 109 Mich. L. Rev. 137, 187-9.

17. Preceding teleological models of trade mark law include: GB Dinwoodie, 'The Death of Ontology: A Teleological Approach to Trademark Law' (1999) 84 Iowa L. Rev. 611; A Kur, 'Strategic Branding: Does Trade Mark Law Provide for Sufficient Self Help and Self Healing Forces?', in I Govaere and H Ullrich (eds), Intellectual Property, Market Power and the Public Interest (P.I.E. Peter Lang, Brussels 2008) 191.

18. Millington v Fox (1838) 40 Eng. Rep. 956, 961-2.

19. FI Schechter, The Historical Foundations of the Law Relating to Trade-Marks (Columbia University Press, New York 1925) 157.

20. FI Schechter, 'The Rational Basis of Trademark Protection' (1927) 40 Harv. L. Rev. 813.

21. Aunt Jemima Mills Co. v Rigney \& Co., 247 F. 407, 409 (2nd Cir. 1917).

22. Tiffany \& Co. v Tiffany Productions, Inc., 147 Misc. 679, 681-2 (N.Y. Sup Ct 1932);

Bulova Watch Co., Inc. v Stolzberg, 69 F.Supp. 543, 547 (D. Mass. 1947). 
attached to his trade mark autonomously. ${ }^{23}$ Furthermore, conceptualizing trade marks as property allows the internalization of advertising value and therefore prevents the appropriation of goodwill by third parties.

The analysis of trade marks under the prism of informational economics ${ }^{24}$ provoked refinements both to the property and to the passing-off strand of thought in regard to trade mark protection. ${ }^{25}$ Specifically, the notion that trade marks serve the economization of consumer search costs provided a new justification for the trade mark-use requirement in suits for infringement. ${ }^{26}$ For the same reason, thresholds for awarding protection have been tightened and dilution protection should only be available upon proof of actual or likely dilutive harm.

A historical compromise between these two polar forces of the trade mark world was reached in Hall $v$ Barrows, where Lord Westbury emphasized that even if trade marks are proprietary in legal nature, the exclusive right could only be trespassed upon when the junior use was confusing. ${ }^{27}$ Consequently, the ostensible conflict between the 'property' and the 'passing-off' mode of thought was, at least in doctrinal terms, resolved by the recognition that property is not an absolutist concept but it may rather describe a bundle of authorities over a tangible or intangible asset, ${ }^{28}$ which may allow other parties some limited use of the same subject matter. ${ }^{29}$ Competitors may avail themselves of some referential uses of senior trade marks, for example. Intellectual property rights entail this regulatory aspect in competition, as they regulate the use of a resource by the economic operators.

Although it has been recognized that the right in a trade mark is proprietary in nature, this seems to have been a pyrrhic victory for the property rationale since the trade mark holder could only enforce his right after having shown that confusion as to source has already occurred or was imminent as a result of the junior use. Furthermore, the expanded protection granted to marks with a reputation, which flows out of the proprietary contemplation of trade mark law, has been considered a fairly undesirable exception to the general principle that a successful suit for trade mark infringement requires the showing of consumer confusion. Responsible for this state of affairs is the idea that the interest position of the public, as far as the enforcement of trade mark law is concerned, is solely referring to the avoidance of confusion in the marketplace. Accordingly, unless a certain trade mark expansion could be justified as necessary for promoting market transparency, there was no room for the respective business interests of the right holder to be included in the circle of interests deemed protectable under trade mark law. Since the right holder would get additional protection without, supposedly, any redeeming benefit for the consuming public, trade mark expansion would overall

23. Yale Electric Corporation v Robertson, 26 F.2d 972, 974 (1928).

24. WM Landes and R Posner, 'Trademark Law: An Economic Perspective' (1987) 30 J.L. \& Econ. 265; R van de Bergh and M Lehmann, 'Informationsökonomie und Verbraucherschutz im Wettbewerbs- und Warenzeichenrecht' (1992) GRUR Int. 588.

25. See generally SL Dogan and MA Lemley, 'A Search-Costs Theory of Limiting Doctrines in Trademark Law' (2007) 97 Trademark Rep. 1223; WP Kratzke, 'Normative Economic Analysis of Trademark Law' (1990-1991) 21 Mem. St. U. L. Rev. 199.

26. SL Dogan and MA Lemley, 'Grounding Trademark Law Through Trademark Use' (2007) 92 Iowa L. Rev. 1670.

27. Hall v Barrows [1863] 46 Eng. Rep. 873.

28. Cf. SM Maniatis, 'Trade Mark Rights - A Justification Based on Property' (2002) 6 I.P.Q. $123,167-71$.

29. Cf. SL Carter, 'Does it Matter that Intellectual Property is Property?' (1992-1993) 68 Chi.-Kent L. Rev. 715. 
be detrimental to consumer welfare. But this way of looking at trade mark law seems to be myopic, because the value that consumers get from trade marks is not simply their source-designating function.

\subsection{Determining the scope of trade mark rights: a balancing exercise}

Despite the scepticism that the property concept was subjected to by legal scholars who were concerned with the anticompetitive effects of trade mark expansion, the exploration of the interest position of the right holder is a very abundant method for examining the relationship between trade marks and competition. There are numerous ways, wholly unrelated to source designation, in which trade marks are being used in competition so as to confer competitive advantage upon the right holder. Some of them might be restricting competition unduly but some others may promote the effectiveness of competition by stimulating dynamic forms of competition. Thus, it becomes apparent that the only way to regulate trade marks in a manner that takes into account their dialectic with the competitive process is to have a closer look at the interests of traders, and grant expanded trade mark protection only in those cases where the enhancement of the legal exclusivity would provide consumers with benefits flowing out of dynamic competition. ${ }^{30}$ The development of trade mark law requires, indeed, new methods to reconcile the interests of right holders and consumers. ${ }^{31}$

Let us now examine whether the right holder has a meritorious case for the protection of the advertising value incorporated into his trade mark and what benefit consumers would derive from the protection of the so-called advertising function of trade marks.

\section{SOME ECONOMIC ASPECTS OF THE ADVERTISING FUNCTION}

\subsection{Product variety and consumer welfare}

In perfectly competitive markets rivalry between sellers of homogenous products drives the price down to the marginal cost of production. ${ }^{32}$ When products become differentiated through branding strategies, consumers will eventually express their preference for the product of their liking. This creates for sellers the possibility of charging supra-competitive prices to the limited extent dictated by the degree of

30. A Chronopoulos, 'Determining the Scope of Trademark Rights by Recourse to Value Judgments Related to the Effectiveness of Competition - The Demise of the Trademark-Use Requirement and the Functional Analysis of Trademark Law' (2011) 42(5) Int'l Rev Intell Prop \& Comp L 535.

31. Cf. LA Heymann, 'The Scope of Trademark Law in the Age of the Brand Persona' (2012) $98 \mathrm{Va}$. L. Rev. 61, 67 (prompting trade mark scholars to consider new ways of reconciling producer and consumer interests); S Dilbary, 'Famous Trademarks and the Rational Basis for Protecting Irrational Beliefs' (2007) 14 Geo. Mason L. Rev. 605 (noting that consumer interests in purchasing luxury and fame incorporated in prestigious trade marks coincide with the proprietary interests of the right holder); Cf. J Davis, 'To Protect or Serve? European Trademark Law and the Decline of Public Interest' (2003) 25(4) E.I.P.R. 180 (arguing that the legal recognition of the so-called economic functions of trade marks promotes the interests of the right holders so that there is a necessity to construct consumer interests as separate and independent from those of traders).

32. LMB Cabral, Introduction to Industrial Organization (Cambridge, MA: MIT Press, 2000) 86. 
demand elasticity. ${ }^{33}$ Consumers pay a price premium but what they get in return is a product tailored to their preferences and a variety of products to choose from. ${ }^{34}$ Meanwhile, static efficiency is reduced because there remain unexhausted economies of scale since each seller is able to serve only a particular segment of the market comprised of those consumers that have a preference for his product. ${ }^{35}$ Nevertheless, product variety increases consumer welfare in spite of the premium it requires to be generated. Of course, a balance should be struck between these two constitutive elements of an effective competitive process. ${ }^{36}$ Sacrifices of economies of scale may be excessive when there is too much product variety, so that consumer welfare decreases eventually. The limits are difficult to draw but the general proposition can be made that consumers are better off when products are differentiated.

Soap, for example, might be differentiated in various respects including its $\mathrm{pH}$, perfume, effect on skin, and, finally, the branding image associated with it. Buyers of soap do not simply consume the generic product but also the information bundled with it creating an image of youthfulness, beauty, sportiness or luxury depending on the advertising strategy of the seller. Within such a multi-dimensional space each seller markets his own bundle of product characteristics seeking to match the preferences of a targeted consumer group. This way of competing resembles the rivalry between gas stations or large retailers choosing their location so as to capture consumers, who form buying decisions while taking into account transport costs (locational competition). ${ }^{37}$

Regardless of the ethical objections to this type of consumption that each one of us might have, consumers demand products differentiated by brand image and they are willing to pay a premium for them. Up to now, courts and commentators have always treated the advertising function of trade marks with suspicion because of its inherent monopolistic tendency to allow the right holder a certain degree of control over the price. ${ }^{38}$ But this is again a valuation based on the obsolete idea that perfect competition is a market structure we should strive to accomplish.

When we consider product variety as a market result brought forward by an effective competitive process, we should not only have in mind direct competitors entering the market with a differentiated product. We should rather focus on the phenomenon of one single brand entering into the economic life and expanding to adjacent or even distant markets. If third parties free-ride on the advertising message of one brand and market their

33. PA Samuelson and WD Nordhaus, Economics (16th edn, McGraw-Hill, New York 1998) 174-5.

34. EH Chamberlin, 'Product Heterogeneity and Public Policy' (1950) 40 AER 85, 88; M Spence, 'Product Selection, Fixed Costs, and Monopolistic Competition' (1976) 43 Rev. Econ. Stud. 217 and 'Product Differentiation and Welfare' (1976) 66 AER 407; AK Dixit and J Stiglitz, 'Monopolistic Competition and Optimum Product Diversity' (1977) 67 AER 297; TB Leary, 'The Significance of Product Variety in Antitrust Analysis', available at <http://www.ftc.gov/public-statements/2000/05/significance-variety-antitrust-analysis>; RS Pindyck and DL Rubinfeld, Microeconomics (7th edn, Pearson Prentice Hall, Upper Saddle River 2009) 445-6.

35. N Kaldor, 'Market Imperfection and Excess Capacity' (1935) 2 Economica 33, 33-4.

36. DW Carlton and JM Perloff, Modern Industrial Organization, 215-19 (4th edn, AddisonWesley, Reading, MA 2005).

37. K Lancaster, 'The Economics of Product Variety' (1990) Marketing Sci. 189, 200; L Pepall, DJ Richards and G Norman, Industrial Organization (Blackwell, Malden, MA 2008) 131-2; O Shy, Industrial Organization, 149 (MIT Press, Cambridge, MA 1995).

38. J Litman, 'Breakfast with Batman: The Public Interest in the Advertising Age' (1998-1999) 108 Yale L.J. 1717, 1728-35. 
product in a distant market without causing confusion, they undermine product variety since they could have entered the market with their own brand and had the hassle of expanding gradually. Consumers would be better off if the participants to economic activity enriched the market with a new brand.

\subsection{Welfare aspects of protecting trader interests in brand extensions}

Protecting trader interests in brand extensions would promote the effectiveness of competition in manifold respects aside from stimulating product variety. Most obviously, spreading the costs of advertisement over multiple products creates economies of scale. ${ }^{39}$ Furthermore, umbrella marketing reduces seller moral hazard. ${ }^{40}$ The right holder is not obliged by trade mark or any other law to constantly hold the quality of his goods at the same level. Given that the cost of production may be volatile for reasons beyond his control, the opposite would have been absurd. But apart from that, the trade mark holder may adjust quality depending on the group of consumers he wishes to target each time. In any event, through the quality function of his trade mark he is identified in the marketplace and therefore subjected to consumer evaluation for the quality he markets. ${ }^{41}$ Punishment of bad quality would then follow since consumers would refrain from dealing with the same seller again. The damage accrued to the seller consists also in the erosion of the quality signal attached to his mark. Nonetheless, the commercial decision of a trader might be to exploit the selling power of his trade mark by gradually lowering quality and capitalizing upon the premium required by his brand to the point that the trade mark is totally eroded. There is not much we can do about this case and the trade mark holder could only be held liable under the conditions set out by other norms such as tort or consumer law. Marketing literature suggests that seller moral hazard is less likely to occur in the context of umbrella marketing because consumer punishment would be much harsher, as it would be administrated over multiple products. ${ }^{42}$ On the other hand, due to the diversity of the products offered, consumers might be willing to forgive partial failure to deliver satisfactory quality, which gives the brand owner a certain amount of elbowroom for error or product experimentation. ${ }^{43}$ In sum, protecting strategies of umbrella marketing secures incentives to maintain good product quality overall.

Both trade mark theory and practice frown upon dilution claims of the right holder seeking to enjoin the use of the mark even for product categories that are totally unrelated to his own goods. The question usually asked is what could the legitimate interest of the right holder be that would legitimize him to enjoin a third party from a non-confusing and obviously not even potentially competing use of the same mark. Marketing literature has some good suggestions for what is actually going on in instances like this. As an example

39. See generally JC Panzar and RD Willig, 'Economies of Scope' (1981) 71 AER 268.

40. LMB Cabral, 'Optimal Brand Umbrella Size' (2007) available at <http://archive.nyu.edu/ bitstream/2451/26209/2/1-6.pdf>; F Andersson, 'Pooling Reputations' (2002) 20(5) Int. J. Ind. Organ. 715.

41. Scandecor Development $A B v$ Scandecor Marketing AB [2002] F.S.R. 7 at [19]: 'Thus, in relying on a trade mark consumers rely, not on any legal guarantee of quality, but on the proprietor of a trade mark having an economic interest in maintaining the value of his mark. It is normally contrary to a proprietor's self-interest to allow the quality of the goods sold under his banner to decline'.

42. Cabral, 'Optimal Brand Umbrella Size', supra (n 40).

43. Ibid. 
of a litigated case ${ }^{44}$ let us consider what might be the point for Nike, the famous producer of sport clothes and shoes, to use its marks on totally unrelated products such as syringes. Or, to turn it around, what sense would it make for a third party entering the market for syringes to adopt Nikepal as a trade mark, namely a mark which is very similar to that of the senior user. Although the attributes of Nike's core brand are not transferrable to syringes, the adoption of the respective trade mark in such a distant market would provide a competitive advantage for the user if product differentiation is virtually non-existent in that distant market. Due to its famousness, the trade mark will slightly differentiate the goods in connection with which it will be used. Even such minimal differentiation would confer a competitive advantage over the products of competitors. ${ }^{45}$

Apparently, the right holder wishes to internalize the capacity of his mark to support this type of differentiating strategy. He might wish to exploit the mark by himself in the same way. Some at first sight strange brand extensions of the past, such as the brand BIC being extended from pens and razors to wind-surfing equipment, could probably be explained under this theory. Another possibility would be to make profit from licensing fees. One wonders why junior users deploying a branding strategy of that kind should obtain a competitive advantage over their competitors in the distant market by free-riding on the goodwill of the senior trade mark. Incumbent firms would then be at a disadvantage that is not attributed to the superior performance of the junior user. Furthermore, if this business practice becomes generalized by third parties entering less differentiated markets with marks similar to those of owners of famous trade marks, the possibility of dilutive harm increases. Instead, the right holder seems to have a legitimate interest in the internalization of the goodwill he has already infused into his trade mark. Requiring third parties to trade on the benefits of their own goodwill spurs dynamic competition with differentiated products. The right holder might wish to keep the possibility of a brand extension to a wholly unrelated product category as an alternative in case he is forced to exit his current field of economic activity.

The protection of the right holder's capacity to effectuate brand extensions could also be a way of ameliorating barriers to exit. When an undertaking has to abandon a market, it will be much easier to do so with the prospect of profitably exploiting goodwill in another market. Sometimes regulation might negatively affect the situation of a competitor, who might then wish to turn to alternative markets for more profitable business. Looking at the tobacco industry, after the prohibitions to persuasive advertising, CAMEL may still be able to make money out of its brand in the clothing industry, for example.

\subsection{The myth of trade marks as entry barriers and pernicious monopolies}

Incumbent trade marks reflect advertising expenditure that has to be borne by outsiders wishing to enter a specific market. It is only in this very broad sense that trade marks may be characterized as barriers to entry in an industry. ${ }^{46}$ Such impediments to new

44. Nike, Inc. v Nikepal International, Inc., 2007 WL 2782030 (E.D. Cal. 2007).

45. LM Pepall and DJ Richards, 'The Simple Economics of Brand Stretching' (2002) 75 J. Bus. 535. (Conversely, when the goodwill attached to a given mark is not transferable to some concentrated distant market with differentiated products, the mark's high degree of distinctiveness will nevertheless facilitate the penetration of the market.)

46. See generally JS Bain, Barriers to New Competition (Harvard University Press, Cambridge, MA 1956) 114-43; RS Brown Jr, 'Advertising and the Public Interest: Legal Protection of Trade Symbols' (1947-1948) 57 Yale L.J. 1165, 1178; CE Mueller, 'Sources of Monopoly Power: A Phenomenon Called "Product Differentiation"” (1968-1969) 18 Am. U. L. Rev. 1; JM 
competition would promote the effectiveness of competition in industries where the cost of entry is low because they would prevent the emergence of excessive variety. ${ }^{47}$ In contrast, if the cost of entry is high, then the impediment to newcomers would keep the number of brands available to consumers at a suboptimal level. ${ }^{48}$ Conclusively, trade marks cannot be condemned per se as anticompetitive barriers to entry. Their effect on competition cannot be ascertained without reference to concrete market constellations and an inquiry on the optimal amount of brands for a specific industry.

Because of their capacity to confer market power upon the right holder, trade marks have been frequently misconceived as pernicious monopolies. Responsible for the misunderstanding was the false attribution of overly large market shares to the loyalty consumers have showed to the brand of the trade mark holder. Exclusive rights in trade marks were subsequently challenged as constituting the core of significant economic positions of particularly high market power. That was the case in Borden where a producer of lemonade enjoyed a market share of nearly 90 per cent, which was allegedly attributed to the popularity of the REALEMON trade mark. The Administrative Law Judge ordered that the restoration of competition would require the right holder to compulsorily license his trade mark. ${ }^{49}$ His decision was reversed on the issue of remedy by the FTC, which pointed out that the dominant position of the trade mark holder flowed out of his aggressive commercial practices in promoting his brand. ${ }^{50}$ Compulsory licensing in the field of trade marks does not seem to be an appropriate remedy since the collective use of the trade mark would obfuscate the efforts of consumers to discern the commercial origin of the goods and hold a single undertaking responsible for the quality of the products marketed under the same mark. ${ }^{51}$

While antitrust theory realized that there is no sense in attacking property rights in trade marks, the same did not unfortunately occur with trade mark theory. Still, courts and commentators adopt a very restrictive stance towards the advertising function of trade marks mainly because of their inherent monopolistic tendency to allow the right holder to compete monopolistically. In reality, trade mark rights may indeed contribute to the emergence and maintenance of positions of economic power but they should not become a scapegoat held responsible for the existence of big players in an industry. No matter how strong or valuable the underlying trade mark is, the large market shares of beverage producers such as those of Coke and Pepsi or a ketchup producer like Heinz could be better explained on other grounds; probably it is the nature of the goods such that it favours companies able to deploy advantages related to economies of scale. Market conditions may lead to an oligopolistic equilibrium. It could also be the result of exclusive dealing or distribution agreements the cumulative effect of which has to be examined by competition law. Hence, there is no need to distort the regulation of product variety through trade mark law in order to dissipate the market power of the right holder.

Livermore, 'On Uses of a Competitor's Trademark' (1968) 20 Stan. L. Rev. 448, 450; Lunney, 'Trademark Monopolies', supra (n 13) at 428-9; AG Papandreou, 'The Economic Effect of Trademarks' (1956) 44 Cal. L. Rev. 503, 508.

47. NS Economides, 'The Economics of Trademarks' (1988) 78 Trademark Rep. 523, 536.

48. Ibid.

49. In re Borden, Inc., 92 F.T.C. 669, 774-6 (1978); see also ML Babin, 'Abuse of Trademarks: A Proposal for Compulsory Licensing' (1973-74) 7 U. Mich. J.L. Reform 644, 661-6.

50. In re Borden, Inc., 92 F.T.C. 669, 802-9, 832-3 (1978).

51. WC Holmes, 'Trademark Licensing as Structural Antitrust Relief: An Analytical Framework' (1981) 71 Trademark Rep. 127, 141-2; see also TJ McCarthy, 'Compulsory Licensing of a Trademark: Remedy or Penalty?’ (1977) 67 Trademark Rep. 197, 231-2. 


\subsection{Marketing and consumer persuasion}

Those rejecting the idea of a broader protection for the advertising value of trade marks make an argument based on the juxtaposition of persuasive to informative advertising. ${ }^{52}$ Protecting the advertising message symbolically codified in a trade mark only makes sense, according to their view, if the relevant information relates to the objective attributes of product or its functionality. On the contrary, the broad protection of the advertising function would provide protection for an artificially created product image. Producers may therefore neglect product quality and waste resources in artificial differentiation. ${ }^{53}$ Moreover, trade mark systems awarding broad protection to the advertising function would set in motion a process of ethical corruption of consumers, who will eventually turn into 'branding personalities'. ${ }^{54}$

None of these arguments is really convincing though. Consumers do not purchase the advertising image as a standalone product but as a complement to some other good. ${ }^{55}$ Thus, sellers cannot disregard the quality of any of the complementary goods without being punished by consumers in the end. As for the ethical reservations against the protection of the advertising function, it could not be argued that in an economic system, where production decisions are taken through the democratic process of the market mechanism, consumers should not demand branded products. ${ }^{56}$ It could not be sustainably argued that trade mark law could justifiably intervene in the building of the individuals' moral system so as to save them from becoming 'branding personalities'.

\subsection{Advertising value as an economic niche in competition}

Differentiation through persuasive advertising entails a monopolistic element since it makes the trade mark owner a local monopolist in the sense that he is able to exercise some control over the price in respect to a specific consumer group, which has a preference for his product bundle. The protection of the advertising function secures for small undertakings an opportunity to retain custom, which under conditions of pure competition on

52. RS Brown Jr, 'Advertising and the Public Interest: Legal Protection of Trade Symbols' (1947-1948) 57 Yale L.J. 1165, 1178; Lunney, 'Trademark Monopolies', supra (n 13) at 427. 53. N Kaldor, 'The Economic Aspects of Advertising' (1950-1951) 18 Econ. Rev. Stud. 1 (arguing that advertising distorts the efficient allocation of resources).

54. For a thorough analysis of this argumentation line see K Assaf, 'Brand Fetishism' (2010-2011) 43 Conn. L. Rev. 8.

55. GS Becker and KM Murphy, 'A Simple Theory of Advertising as Good or Bad' (1993) 108 Q. J. Econ. 941, 945-52.

56. McCarthy, 'Compulsory Licensing of a Trademark', supra (n 51) at 243-53 citing the opinion of J Harlan in Federal Trade Commission v Procter \& Gamble Company, 368 U.S. 568, 603 (1967): 'Undeniably, advertising may sometimes be used to create irrational brand preferences and mislead consumers as to the actual differences between products, but it is very difficult to discover at what point advertising ceases to be an aspect of healthy competition. ... It is not the Commission's function to decide which lawful elements of the "product" offered the consumer should be considered the symptoms of industrial "sickness." It is the consumer who must make that election through the exercise of this purchasing power'. See also TJ McCarthy, 'Trademarks, Antitrust and the Federal Trade Commission' (1979-1980) 13 J. Marshall L. Rev. 151, 156: 'The fallacy of this approach [namely that brand loyalty constitutes irrational consumer behaviour] seems self-evident to me because it is based on an essentially undemocratic thesis: the consumer should not want what he or she wants'. 
price and output would not have been possible. Trade marks confer upon their right holders a certain degree of market power that is necessary for them in order to be able to profitably market their products. Product differentiation creates a niche for brand owners, which allows them to survive price competition from well-established rivals. Maintaining economic niches in competition does not amount to a protectionist concern for weaker competitors but it is meant to promote diversity in the supply side of the market for the benefit of consumers. ${ }^{57}$ A single monopolist would also be able to offer the optimal amount of product variety; he could nevertheless be inclined to restrict output and raise prices so as to maximize profit. For him, offering the desired amount of product variety would only make sense as a predatory strategy envisioning monopolization after undercutting competitors. Economic niches are footholds facilitating internal expansion of firms and, in the long run, economic growth. ${ }^{58}$

\subsection{Is there a tort of misappropriation?}

Free-riding on the advertising value of another amounts to a misappropriation because it undermines the effectiveness of competition. This conclusion is in line with the ruling of the infamous case of Int'l News Serv. v Associated Press. ${ }^{59}$ There, the US Supreme Court condemned misappropriation as an attempt of a competitor to 'reap where it has not sown' or to appropriate 'the harvest of those who have sown'. In essence though, the court sought to avoid the collapse of the market for news that would arise in the long run if the economic operator able to collect and disseminate the relevant information were subjected to competitive pressure from free-riders, who were not bearing the cost of production. ${ }^{60}$ It follows that misappropriation occurs when free-riding undermines the effectiveness of competition. ${ }^{61}$

\section{LIMITS TO GOODWILL PROTECTION}

\subsection{Anticompetitive branding strategies: brand proliferation}

Brand proliferation refers to the business strategy of marketing a diverse brand portfolio with the purpose of approaching various consumer groups with different preferences. From the perspective of large incumbent firms it could serve as a means to prevent the emergence of new competition by covering up the segments of the fictitious product space and eventually depriving newcomers of a profitable market niche that would provide a chance of survival in the marketplace. ${ }^{62}$ Established firms could blanket new market entry by lowering the price for the brand

57. C Tisdell and I Seidl, 'Niches and Economic Competition: Implications for Economic Efficiency, Growth and Diversity' (2004) 15 Struct. Chang. Econ. Dyn. 119.

58. Ibid.

59. Int'l News Serv. v Associated Press, 248 U.S. 215 (1918).

60. Ibid at 240-41.

61. In more detail, A Chronopoulos, 'Trade Dress Rights as Instruments of Monopolistic Competition: Towards a Rejuvenation of the Misappropriation Doctrine in Unfair Competition Law and a Property Theory of Trademarks' (2012) 16(1) Marq. Intell. Prop. L. Rev. 119, 137-8; English courts do not seem willing to accept the existence of a tort of unfair competition without misrepresentation, L'Oréal SA v Bellure NV, [2007] EWCA Civ 968 at [135] et seq.

62. R Schmalensee, 'Entry Deterrence in the Ready-to-Eat Breakfast Cereal Industry' (1978) 9 Bell J. Econ. 305. 
corresponding to a certain market niche and recoup losses after having defended the relevant market successfully. In the case In re Kellogg Co. et al. suit was filed against a group of breakfast cereal producers on the basis of s 5 FTC Act for foreclosing the market through entry barriers by virtue of brand proliferation strategies. ${ }^{63}$ As collusion could not be proved, the complaint brought forward a 'shared monopoly theory' arguing that the result of the aforementioned business practices was that the defendants were actually sharing the market. The FTC rejected the complaint with the argument that there was no evidence of market performance appertaining to an industry structure of monopoly. ${ }^{64}$ Incumbent firms had neither restricted output nor raised prices and they have been introducing new products in the meantime.

Despite FTC's refusal to recognize the impediment of market entry through brand proliferation as a separate theory of anticompetitive harm, there are very good reasons for adopting the opposite view. Incumbent firms would remain free from intense competitive pressure for a long time since only firms able to enter the market while selling multiple brands would be serious competitors. Without competitive pressure, product variety would tend to be suboptimal in the long run because the established firms would differentiate till the point of their profit maximization. Even if brand proliferation does not eliminate market entry, it pays in cases like Kellogg, as a matter of competition policy, to make the market more contestable.

\subsection{Goodwill transferability}

Goodwill protection cannot be limitless. As already suggested, there is an optimal degree of product variety and, accordingly, an optimal amount of brands in an industry. In this respect, the limits to the protection of the advertising function of trade marks need to be further inquired upon by economic theory.

Against the protectability of the advertising function has been often contended that trade marks should not be morphed into copyrights in advertising message. ${ }^{65}$ The argument suggests that the subject matter of both intellectual property rights should be distinguished so that each exclusive legal position maintains its own field of authority. Implied therein lies the notion that trade marks may not have the same exclusionary effect as copyrights since the subject matter of the latter has always been considered as supposedly requiring more creative capacity than business goodwill. Competition would be unduly restricted if commercial source designators mutated into copyrights in marketing image.

While the concerns over the broad exclusionary effect of trade mark rights in marketing message deserve consideration, the protection of the advertising function of trade marks promotes consumer welfare. Therefore, it would be more appropriate to seek for rational limits to the protection of advertising value through trade mark law instead of trying to undermine the legal relevance of the advertising function. The starting point of our analysis is the interest of the right holder to expand his core brand to other adjacent or distant markets as a business strategy that enhances the effectiveness of competition. Seen under the prism of source confusion, trade mark infringement analysis makes an inquiry on whether consumers are likely to

63. In re Kellogg Co. et al., 99 F.T.C. 8 (1982).

64. Ibid at 267.

65. Wagamama Ltd v City Centre Restaurants Plc, [1995] F.S.R. 713, 731; see also GE Middleton, 'Some Reflections on Dilution' (1952) 42 Trademark Rep. 147, 178-80; M Richardson, 'Copyright in Trade Marks? On Understanding Trade Mark Dilution' (2000) 4 I.P.Q. 66. 
conclude that the right holder could use his mark in connection with products or services offered for sale in another market given his entrepreneurial structure, facilities and expertise. When it comes to the likelihood of confusion as to economic, organizational or other affiliation, the inquiry is directed at examining whether the junior user appropriates the mark for product categories, the marketing of which has been, in the view of consumers, outsourced or somehow approved by the right holder. Junior uses creating merchandising products or implying sponsorship of some athletic or cultural event are likely to be infringing as causing such a type of confusion.

An inquiry on the transferability of goodwill to other markets requires a different type of analysis when the interest of the right holder in extending his brand is concerned. Goods or services would then be proximate to the core brand if the marketing message of the right holder is transferable to a specific market in the sense that it can complement and stimulate demand for the respective products or services. ${ }^{66}$ Under this test, product similarity would be established more easily than when a decision on trade mark infringement has to be reached pursuant to a confusion-based theory of liability. Taking the famous trade mark 'INTEL' registered for computer products as an example, it would be difficult to establish that the right holder would offer telemarketing or communication services or sponsor other companies that do so. However, the brand image of the right holder connoting speedy technological processes offering some service to the consumer is indeed transferable to those markets. For the sake of promoting dynamic competition with differentiated products, this advertising value should be internalized through trade mark rights. The goodwill of the right holder would not be transferable to nutrition products, for example. By defining the market segments in which the right holder has a legitimate interest to exploit his goodwill, it becomes possible to award legal protection to the advertising function without granting trade marks the exclusionary effect of copyrights.

\subsection{Public policy considerations - the effect of advertising regulation on the protection of goodwill}

Once the legislator decides to impose restrictions on persuasive advertising in a particular market for reasons of public health, for instance, trade mark law should not run contrary to that policy decision. Legal restrictions on advertising should have an impact on the scope of protection of the advertising function in trade mark law. The tobacco industry might be proven to be an example where the legislator would be prone to reduce incentives for the generation of advertising value based on brand image.

\section{REVISITING BRIEFLY SOME DECISIONS OF THE CJEU ON TRADE MARK INFRINGEMENT}

Articles 4(4)(a) and 5(2) TMD establish dilution and free-riding as equally plausible theories for the protection of marks with a reputation. In the past, the cause of action resting on free-riding had been marginalized mainly due to the lack of a plausible

66. CW Park, S Milberg and R Lawson, 'Evaluation of Brand Extensions: The Role of Product Feature Similarity and Brand Concept Consistency' (1991) 18 J. Consum. Res. 185; DA Aaker and KL Keller, 'The Effects of Sequential Introduction of Brand Extensions' (1992) 29 J. Marketing Res. 35, 36. 
rationale for the misappropriation doctrine. ${ }^{67}$ Although the CJEU has provided significant guidance as to the interpretation of the term 'unfair advantage' in L'Oréal and Specsavers, there is still uncertainty among commentators about the validity of the free-riding argument. ${ }^{68}$

\subsection{L'Oréal and Specsavers}

In L'Oréal, a third party used the get-up of the right holder's well-known brands for its own smell-alike products. After deciding to re-launch its optician services, large retailer Asda imitated the marketing scheme of Specsavers, who are well-known opticians in the UK. Its advertising campaign was based on the slogans 'Be a real spec saver at Asda' and 'Spec Savings at Asda'. In addition, Asda had used a pictorial mark consisting of two non-intersecting ovals containing the words 'ASDA' and 'OPTICIANS' respectively. The junior mark came very close to the trade mark of Specsavers, consisting of two intersecting ovals with the word 'SPECSAVERS' placed across them.

In the view of the court, creating a link to a senior trade mark with a reputation in order to benefit from its power of attraction confers upon the junior user an unfair advantage when the latter has not compensated the right holder and does not perform his own marketing efforts to promote his products. It seems that the CJEU adopts an argumentation where the unfairness of free-riding is primarily based on an ethical condemnation of the riding on the coat tails of another's investment. ${ }^{69}$ The concept of 'unfair advantage' is accordingly held as being tautological with 'parasitism'. ${ }^{70,} 71$ Importantly, the analysis

67. A Ohly, 'The Freedom of Imitation and its Limits - a European Perspective' (2010) IIC 506, 518; H Carty, 'Do Marks with a Reputation Merit Special Protection?' (1997) 19(12) E.I.P.R. 684; M Spence, 'Passing Off and the Misappropriation of Valuable Intangibles' (1996) 112 L.Q.R. 472, 4757. On the difficulties of defining 'unfair advantage' as a legal term see generally, A Blythe, 'Attempting to Define Unfair Advantage: An Evaluation of the Current Law in Light of the Recent European Decisions' (2012) 34(11) E.I.P.R. 754; cf. the analysis of IS Fhima, Trademark Dilution in Europe and the United States (Oxford University Press, Oxford 2011) 189-96.

68. D Gangjee and R Burrell, 'Because You're Worth It: L'Oréal and the Prohibition on Free Riding' (2010) M.L.R. 73(2), 282; D Meale and J Smith, 'Enforcing a Trade Mark When Nobody's Confused: Where the Law Stands After L'Oréal and Intel' (2010) 5(2) J.I.P.L.P. 96, 103. See also CJ Craig, 'Perfume by Any Other Name May Smell as Sweet ... But Who Can Say? A Comment on L'Oréal v Bellure' (2010) 22 I.P.J. 321; H Ullrich, 'Intellectual Property: Exclusive Rights for a Purpose - the Case of Technology Protection by Patents and Copyright' Max Planck Institute for Intellectual Property \& Competition Law Research Paper No. 13-01, at 35 (commenting on the ruling of the CJEU in L'Oréal and disfavouring the expansion of the legal exclusivity by the legal recognition of further 'economic functions' of trade marks). However, cf. the insightful analysis of M Lehmann, 'Die wettbewerbswidrige Ausnutzung und Beeinträchtigung des guten Rufs bekannter Marken, Namen und Herkunftsangaben: Die Rechtslage in der Bundesrepublik Deutschland' (1986) 6 GRUR Int. 14-16 (in favour of the free-riding theory and critical of the 'freedom of imitation' as a normative principle).

69. L'Oréal SA, Lancome Parfums et Beauté \& Cie and Laboratoire Garnier \& Cie v Bellure $N V$, Malaika Investments Ltd (trading as Honeypot Cosmetic \& Perfumery Sales) and Starion International, Court of Appeal, England and Wales [2010] EWCA Civ 535, at [49]-[50] (Jacob LJ, Wall LJ, Rimer LJ). See also B Trimmer, 'The Power of Attraction: Do Trade-Marks Have an "Image" Problem in the English Courts?' (2009) 31(4) E.I.P.R. 195 (describing the reception of the free-riding theory of the CJEU by the English court).

70. L'Oréal at [41]; on this argument see also FW Mostert, 'The Parasitic Use of the Commercial Magnetism of a Trade Mark on Non-Competing Goods' (1986) 8(11) E.I.P.R. 342, 346-8.

71. Ibid at [49]. 
of the court in L'Oréal focuses on the predatory intent of the junior user as objectively manifested in his commercial practices, which could not have any other purpose than taking advantage of the selling power of a senior trade mark. ${ }^{72}$

However, the unfairness, as a legal term within a system of laws that promote the effectiveness of the competitive process, should not be interpreted in the light of ethical arguments, which are anyway of ambivalent convincing value, but with reference to the effect of the absence of protection to competition. The court seems indeed to encourage the participation in competition with one's own marketing efforts. But the deeper justification for the adoption of such a rule for the competitive process lies in the welfare effects that a dynamic competition with differentiated products can promulgate. Protecting Specsavers in the specific case would coerce Asda to compete by substitution. This would in turn enhance consumer welfare by increasing product variety. Moreover, Specsavers seeks in this case protection for its economic niche against price competition from a large retailer. Such protection promotes diversity and product variety in competition. Most importantly, the protection of an economic niche based on marketing image stimulates dynamic competition with differentiated products, where firms compete on better matching consumer preferences. Nothing prevents Asda from luring away the customers of Specsavers through the creation of a differentiated and superior goodwill.

However, the CJEU has not yet come to clarify wherein exactly the unfairness of goodwill appropriation lies and seems not to take into account the specific competitive circumstances under which free-riding occurs.

Therefore, the opinion of Advocate General Mengozzi, who argued that free-riding on the reputation or the image of a senior trade mark is per se unfair within the meaning of Article 5(2), while the junior user may bring forward a plausible justification so as to escape liability, is better in describing the free-riding theory in my view. ${ }^{73}$

\subsection{Intel: a critical view}

While Specsavers dealt with instances of free-riding between competitors and L'Oréal involved the transfer of goodwill from a luxury good to a low priced knock-off, Intel ${ }^{74}$ was essentially a case that called for considering the interests of traders in brand extensions.

The Intel Corporation was the proprietor of the word mark 'INTEL' registered for computer and computer-linked products and services. On the basis of its trade mark rights Intel filed an application for a declaration of invalidity against the registration of the word mark 'INTELMARK', which had been registered for marketing and telemarketing services. Intel claimed that the use of the junior mark would take unfair advantage of, or be detrimental to, the distinctive character or the repute of its trade mark.

The opinion of the CJEU dealt mainly with some important problems related to the theories of detriment and degradation. It is arguable though whether dilution theory is the pertinent analytical instrument for legally evaluating such a set of facts. Dilutive harm is difficult to prove and empirical evidence does not support the proposition that negative consumer valuations of brand extensions are likely to become detrimental

72. Ibid at [48].

73. Opinion of Advocate General Mengozzi in L'Oréal SA v Bellure NV, Case C-487/07, [2009] E.T.M.R. 55, at [108].

74. Intel Corporation Inc. v CPM United Kingdom Ltd, Case C-252/07, [2009] E.T.M.R. 18. 
to the core brand. ${ }^{75}$ A case for dilution could possibly be brought forward when the right holder runs the danger of his mark becoming a marketing buzzword and experiencing a slow martiric 'death by a thousand stings'. Third parties have been using the mark 'INTEL' in connection with all sorts of products like construction services ('INTELGROW' or 'INTELSPECS'). Of course, the right holder should have the possibility of arguing that the dilution of his mark is likely to occur as a consequence of the cumulative effect of such uses. Notably, the free-riding theory determines a trade mark scope which is narrower than the one that would have been enforced if the dilution cause of action were successful under the same set of facts since the goodwill attached to the senior mark does seem to be transferable to the services marketed by the junior user.

An example of a proper free-riding analysis was delivered by the First Board of Appeal of OHIM in a case that also turned upon the rights of Intel Corporation in its well-known word mark. ${ }^{76}$ Specifically, the issue was whether a third party could use the senior trade mark for marketing services as well as for providing facilities for fairs and exhibitions in the electronic, electro-technical and lighting field. Reversing the decision of the Opposition Division, the Board of Appeal argued that despite the low similarity of the respective products and services, the fact that both parties were operating in an overlapping commercial context would in all likelihood give rise to a future image transfer. ${ }^{77}$ The decision illustrates the point that product similarity is evaluated differently and might well also be affirmed even in the case of products that are greatly dissimilar for giving rise to the likelihood of confusion or even dilution when the assessment is made within the framework of a free-riding theory of infringement.

Within the framework of an infringement analysis addressing trader interests in brand extensions and consumer welfare arising from more dynamic forms of competition, product similarity becomes the most important inquiry, which is directed at examining the transferability of a certain brand image to the products of another market. If the products or services of the market of the junior use are a good fit in marketing terms for the core brand of the right holder, infringement would be established even if the link to the senior trade mark is weak, as likely to arise in the future.

A very high reputation increases the strength of the link but also the possibility of goodwill transferability. Uniqueness also plays a role, in that it enlarges the scope of the trade mark, although marks that have acquired their distinctiveness through use may also allow the right holder to prevent goodwill appropriation. Marks comprising of words belonging to the common vocabulary would be descriptive or suggestive for some product categories and therefore third parties operating in these markets would be entitled to their use. ${ }^{78}$ For the referential uses permitted by trade mark law, third parties would have a due cause within the meaning of Article 5(2) TMD for using the senior trade mark.

75. MP McKenna, 'Testing Modern Trademark Law's Theory of Harm' (2009) 95 Iowa L. Rev. 66; R Tushnet, 'Gone in Sixty Milliseconds: Trademark Law and Cognitive Science' (2007-2008) 86 Tex. L. Rev. 507.

76. Decision of the First Board of Appeal, 22 October 2004, in case R 782/2002-1, Inter Corporation v Intel-Internazionale Elettrotecnica Associazione. See also Antartica Srl v OHIM, Case T-47/06, [2007] E.T.M.R. 77, commented on by SM Maniatis and D Botis, Trade Marks in Europe: A Practical Jurisprudence (2nd edn, Sweet \& Maxwell, London 2010) 467-70.

77. Ibid at [66].

78. In more detail, A Chronopoulos 'Goodwill Appropriation as Distinct Theory of Trademark Liability - An Enquiry on the Misappropriation Rationale in Trademark and Unfair Competition Law' (forthcoming 2014) 22 Tex. Intell. Prop. L. J. 
In contrast to the concept of dilution, the free-riding theory provides an analytical framework that effectively takes into consideration all competitive aspects related to brand extentions.

\subsection{Puma v Sabel}

Without doubt, one of the most significant opinions of the CJEU on the advertising function up to now is the one rendered in Case C-251/95 - Sabel BV v Puma AG, Rudolf Dassler Sport. ${ }^{79}$ Both parties to the dispute were in the clothing and footwear business. Puma asserted trade mark rights in a pictorial mark depicting a bounding feline. Specifically, it sought to oppose the registration of a similar composite mark comprising the image of a bounding feline, the word mark 'SABEL' and some other embellishment. The court was called upon by the Federal Supreme Court of Germany to clarify the meaning of Articles 4(1)(b) and, consequently, 5(1)(b) of the TMD in the context of a preliminary ruling.

The crux of the matter was really whether the likelihood of association constitutes a distinct theory of trade mark liability granting protection against dilution or free-riding even to those marks that do not satisfy the threshold of reputation required by Article 5 (2) TMD. Under the Uniform Benelux Trademark Act of 1971 likelihood of association constituted indeed a theory of trade mark infringement that was independent from any finding of consumer confusion. ${ }^{80}$ Trade mark infringement had been broadly conceptualized as an act that adversely affected the interest position of the right holder by creating associations to his senior mark. ${ }^{81}$ Rudolf Callmann had also envisioned a theory of trade mark infringement directed at the parallel prohibition of both confusing and misappropriative junior uses. ${ }^{82}$

In the view of the court, the wording of the said provisions clearly established the term likelihood of confusion as the ground upon which liability attaches and as a superordinate term encompassing the likelihood of association. Source confusion is supposed to result from an association between a senior and a junior mark. ${ }^{83}$ The reference to the likelihood of association is, according to the court, simply meant to deliminate the scope of the protection granted under Articles 4(1)(b) and 5(1)(b) TMD. ${ }^{84}$ In corroboration of its argument, the court referred to the tenth recital of the preamble of the TMD, which stipulates that the likelihood of confusion constitutes the 'specific condition' for such protection. ${ }^{85}$ Finally, the CJEU made an argument $e$ contrario out of the exceptional character of the extended protection against dilution and free-riding offered to owners of marks with a reputation. Accordingly, all other marks - leaving aside identical uses - require proof of likelihood of confusion for their protection. ${ }^{86}$

79. Sabel BV v Puma AG, Rudolf Dassler Sport, Case C-251/95, [1998] E.T.M.R. 1.

80. C Gielen, 'Benelux', in FW Mostert and P Anand (eds), Famous and Well-Known Marks: An International Analysis (2nd edn, International Trademark Association, New York 2004) 4-63-4-66; P Blondeel, 'The Likelihood of Confusion and the Likelihood of Association in Benelux and Community Trademark Law: Concepts, Interpretations and Evolutions', Presentation at the Fifth European Trademark and Design Judges' Symposium, Alicante 27-28 September 2007, available at <http://oami.europa.eu/en/office/ejs/pdf/Blondeel.pdf>.

81. Article 13A of the Benelux Trademark Act of 1971.

82. R Callmann and L Altman, Unfair Competition, Trademarks and Monopolies, supra (n 5)

§ 17:9-17-64.

83. Puma at [18].

84. Ibid at [18].

85. Ibid at [19].

86. Ibid at [20]-[21]. 
A teleological argument for confining the scope of trade mark rights to the protection of the origin function places the emphasis on the avoidance of overbroad exclusive legal positions, which would burden the freedom of competition with monopolistic elements. ${ }^{87}$ The late $\mathrm{J}$ Laddie had made this point very adamantly in Wagamama Ltd $v$ City Centre Restaurants Plc. ${ }^{88}$ There, the owner of Japanese-style restaurants and proprietor of the trade mark 'WAGAMAMA' sought to enjoin a third party from using the mark 'RAJAMAMA's' in connection with the services provided by its Indian restaurant. Likelihood of association was not considered as an actionable type of confusion because it would extend the trade mark scope beyond the level necessary for protecting the right holder's reputation. ${ }^{89}$ Trade mark rights should be anchored at the protection of the origin function otherwise they would be tantamount to undue restrictions on competition. ${ }^{90}$

Several objections may be put forward against the legal syllogism of the CJEU. ${ }^{91}$ First of all, the argument based on the wording of the Directive is not as strong as it seems to be. Furthermore, as the governments of Belgium, Luxemburg and Netherlands argued in the Sabel case, the likelihood of association was introduced into the Directive at the example of Benelux trade mark law, which, as already mentioned, gave authority to the right holder to enjoin those junior uses that were detrimental to his interest position by causing an association to his trade mark. For sure, the legislative history is not clear enough to support an argument for the rejection of the concept of likelihood of association as a trade mark infringement theory. ${ }^{92}$ In addition, it is plausible to assume that the term 'confusion' in Articles 4(1)(b) and 5(1)(b) TMD could be understood as referring to different types of actionable confusion, one of them being the likelihood of association.

All these uncertainties associated with the arguments appertaining to the letter or the legislative history of these provisions necessarily shift the focus of the legal evaluation to the ground of teleology. Requiring the defendant to refrain from adopting a marketing concept that shares the same conceptual features with the goodwill of the trade mark proprietor would promote a dynamic competition with differentiated products. Hence, under the free-riding theory of protection, trade mark infringement should be conceptualized as conduct that undermines consumer welfare in terms of product variety. On top of everything, it is not only the owners of well-known marks that are in need of protection. Smaller competitors are actually even more dependent on the protection of their economic niche, which is possible through the internalization of the advertising value of their trade marks.

\subsection{The impairment of a trade mark function as a limiting concept}

In L'Oréal the CJEU opined that Article 5(1)(a) TMD, granting authority to the right holder to prohibit identical uses, is also meant to protect trade mark functions other than the origin function. ${ }^{93}$ Also included therein is the advertising function. The court

87. M Elsmore, 'Sabel v. Puma - Confusion is King' (1998) Sep J.B.L. 485, 492-3.

88. Wagamama Ltd v City Centre Restaurants Plc, [1995] F.S.R. 713.

89. Ibid at $728-31$.

90. AG Jacobs endorsed the monopoly concerns expressed by J Ladie; see Opinion of Advocate General Jacobs delivered on 29 April 1997 in Case C-251/95 - Sabel BV v Puma AG, Rudolf Dassler Sport; see also GJ van de Kamp, 'Protection of Trade Marks: The New Regime - Beyond Origin?' (1998) 20(10) E.I.P.R. 364, 369 (arguing also that an additional type of actionable consumer confusion would impede the free movement of goods).

91. Cf. Anselm Kamperman Sanders, 'The Wagamama Decision: Back to the Dark Ages of Trade Mark Law' (1996) E.I.P.R 18(1) 3 (with a critical view on the opinion of J Laddie).

92. Opinion of Advocate General Jacobs in Puma at [43].

93. L'Oréal at [58]. 
held that the provision at issue is meant to grant trade mark protection even against nonconfusing uses. Moreover, the trade mark holder is authorized to enjoin every junior use that affects or is likely to affect the functions of communication, advertising and investment. In regard to the advertising function this would mean that the right holder could only oppose free-riding of advertising value when he is able to prove damage resulting from the junior use such as lost sales. ${ }^{94}$ According to the opinion of the Advocate General Mengozzi this is exactly what differentiates Articles 5(1)(a) and 5(2) of the TMD as far as unfair advantage is concerned. ${ }^{95}$ Through the requirement of an impairment of a trade mark function, the free-riding theory is, again, confined to marks with a reputation.

But instead of trying to avoid an alleged inconsistency between Article 5(1)(a) and 5(2) TMD, ${ }^{96}$ we should perhaps take into consideration that the free-riding concept should be recognized as a distinct theory of trade mark liability, which should stand next to confusion-based or dilutive harm-based theories of infringement on an equal footing. The deliverance of the free-riding theory is dictated by considerations related to the effectiveness of dynamic competition with differentiated products. After all, free-riding on advertising value could also be held to constitute an impairment to the advertising function, as it is interfering with the internalization of the intangible value of goodwill for the benefit of the right holder.

\section{CONCLUSION}

Trade marks do much more than designate commercial source and economize on search costs. They incorporate the differentiation strategy of the right holder and thereby render his advertising message an economic good, which can eventually be consumed or traded. The advertising function of trade marks has been traditionally awarded recognition only to the extent of its overlap with the origin function or it has been considered a privilege only available to the owners of marks with a reputation. Behind this legal state of affairs stands the rejection of the property rationale and the prevalence of the idea that extended protection should be granted for those marks that reflect in their high degree of recognition a significant business performance. ${ }^{97}$ Nevertheless, the preceding analysis has indicated that the protection of advertising value through trade mark law finds its justification in the welfare aspects of dynamic competition with differentiated products. Trade mark protection beyond the paradigm of consumer confusion as to source or dilutive harm is, thus, dictated by value judgments related to the effectiveness of competition and not by the need to legally implement some 'economic functions' of trade marks. ${ }^{98}$ The free-riding theory of protection is the most pertinent doctrinal tool for the legal evaluation of the branding activity because it can squarely address the diverse interests involved in the respective disputes.

94. Ibid at [60].

95. Advocate General Mengozzi, L'Oréal at [61].

96. M Spence, 'Section 10 of the Trade Marks Act 1994: Is There Really a Logical Lapse?' (2001) 23(9) E.I.P.R. 423; A Horton, 'The Implications of L'Oréal v Bellure - a Retrospective and a Looking Forward: The Essential Functions of a Trademark and When is an Advantage Unfair?' (2011) 33(9) E.I.P.R. 550, 555.

97. BW Pattishall, 'The Dilution Rationale for Trademark - Trade Identity Protection, Its Progress and Prospects' (1977) 67 Trademark Rep. 607, 624; DS Welkowitz, Trademark Dilution: Federal, State and International Law (BNA, Washington DC 2002) 13-4.

98. See generally Chronopoulos, 'Determining the Scope of Trademark Rights by Recourse to Value Judgments Related to the Effectiveness of Competition' supra (n 30). 